\title{
Ecological Civilization: Interpreting the Chinese Past, Projecting the Global Future
}

\author{
Mette Halskov Hansen, University of Oslo, Norway \\ Hongtao Li, Zhejiang University, China \\ Rune Svarverud, University of Oslo, Norway

\begin{abstract}
Submitted final version - to be published in Global Environmental Change, vol 23, November 2018, pp. 195-203
\end{abstract}

\begin{abstract}
Ecological civilization (shengtai wenming 生态文明) has been written into China's constitution as the ideological framework for the country's environmental policies, laws and education. It is also increasingly presented not only as a response to environmental degradation in China, but as a vision for our global future. In this article, scholars from the disciplines of media science, anthropology and sinology analyse media representations of ecocivilization in order to explore which values and visions this highly profiled state project actually entails. The article argues that eco-civilization is best understood as a sociotechnical imaginary in which cultural and moral virtues constitute key components that are inseparable from the more well-known technological, judicial, and political goals. The imaginary of ecocivilization seeks to construct a sense of cultural and national continuity, and to place China at the center of the world by invoking its civilization's more than 2000 years of traditional philosophical heritage as a part of the solution for the planet's future. It is constructed as a new kind of Communist Party led utopia in which market economy and consumption continue to grow, and where technology and science have solved the basic problems of pollution and environmental degradation.
\end{abstract}

Keywords: Ecological civilization, sociotechnical imaginary, environmental policy, global ecological future, eco-philosophy, China

\section{Introduction}

The concept of ecological civilization, or eco-civilization (shengtai wenming 生态文明), may still sound obscure to readers unfamiliar with Chinese political discourse and civilization campaigns. In the official English translation of then President Hu Jintao's speech for the 18th Party Congress in 2012, the Chinese term "shengtai wenming" was even translated as "ecological progress" (rather than "ecological civilization"), possibly in order not to confuse an international audience unfamiliar with using the term "civilization" in this way. (China Daily, 2012). However, since its introduction into China's Communist Party's ideology in 2007, and especially after President Xi Jinping endorsed it in 2013 as a major framework for the country's environmental laws and policies, it has gained traction in Chinese society and in 2018 it was elevated to a more prominent position in the constitution. Since 2007, more than 4,000 published Chinese articles and books have included eco-civilization as one of their key 
words, and more than 170,000 articles in mainstream press-media in China have invoked the concept (Heurtebise, 2017, p. 7). The rest of the world is likely to hear more about ecological civilization as China strengthens its global position as a climate actor while simultaneously continuing its policy of rapid economic growth moving beyond China through, most prominently, the prestigious infrastructure project, the Belt and Road Initiative (yidai yilu 带一路, see e.g. Cai 2017). There is no doubt that the global environmental mark of the world's second largest economy will continue to grow considerably in the near future. The rapid increase in China's fossil fuel consumption has long outpaced the scenarios foreseen by scholars as late as in the 1990s; and already by 2007, China was the world's leader in emissions of greenhouse gasses (Sternfeld 2018). At the same time, ecological civilization is promoted as a vision of a society characterized by ecologically sustainable modes of resource extraction, production and trade, inhabited by environmentally conscious and responsible citizens.

We argue in this article that ecological civilization, or eco-civilization, currently constitutes the most significant Chinese state-initiated imaginary of our global future, and that it is therefore crucial to explore in more detail what this vision entails. Does it reflect a desire for an environmentalist turn towards a world less driven by economic incentives and with more equal distribution of resources, or is it an attempt to strengthen China's current path of development? Already now, eco-civilization has become the ideological framework for the government's development of new and stricter environmental policies and laws, and it has significant implications for Chinese society, its citizens and the country's international policy (Delman, 2018; Ahlers and Hansen, 2017; Ahlers and Shen, 2018; Kostka and Nahm, 2017; Shin, 2017). In fact, the Chinese state with all of its overwhelming environmental problems is still the only one that has attempted at formulating a broad vision for the global future focusing on the environment. Eco-civilization emerged as a result of the political leadership's recognition of the magnitude of environmental and climate related challenges that China is facing, and as shown in a recent study by Jørgen Delman (2018), it has already had a profound effect on environmental governance in local areas. However, in addition to setting an agenda for concrete political initiatives, ecological civilization is an imaginary that draws on specific interpretations of the Chinese philosophical past in order to create a vision for the global future that is rooted in national identity. The eco-civilized future is cast as a utopian alternative to the blind pursuit of industrial growth that developed in what is presented, in official Chinese discourse, as the destructive Western industrial civilization (gongye wenming 工业文明) since the 18th century (Pan, 2003). To paraphrase the Chinese government, the imaginary of eco-civilization can be described as "a socialist-ecological future with Chinese characteristics" (Jiang, 2013).

The imaginary seeks to construct a sense of Chinese cultural continuity, and by invoking the very concept of civilization (wenming 文明) it also manages to situate itself in a longer historical tradition in which the Chinese elite, since the early 20th century, has adopted a dominant Western European understanding of science as a key to civility, and of civility as a marker of global order (Messner, 2015, p. 241; Pernau and Jordheim, 2015). In our age of deep global environmental concern, the imaginary of eco-civilization places China at the center of the world map by invoking its 2500 years of traditional philosophical heritage as part of a solution for the planet's future. This perception of China's past has flourished among scholars in China already since the late 1980s (see e.g. Schmitt, 2016, pp. 77-80). However, our discussion of eco-civilization takes a different direction than these largely normative debates. We explore, from a critical perspective, how authoritative writers on eco-civilization and official media have chosen to draw on selected interpretations of traditional philosophical texts, as well as on lessons or examples drawn from China's socialist pasts, in order to create a cultural-national basis for the imaginary of eco-civilization. We ask what social, 
technological, and political values the vision of eco-civilization actually promotes, and how its key messages are transmitted to the population. How are Chinese citizens introduced to the promises made by the vision of eco-civilization, and what is expected of future eco-civilized citizens and government officials.

Scholars have approached eco-civilization as an ideology and as a political framework, plan and vision (e.g. Schmitt, 2016; Delman; Geall, 2015). In order to better capture its many facets, we suggest (in accordance with Hansen and Liu, 2018) that it is best understood as a socio-technical imaginary. The reason is that the analytical concept of sociotechnical imaginary, as first coined by Sheila Jasanoff (2015a, 2015b), opens up for an analysis of how technological values and visions of the future are interwoven with political, social and cultural ones. This, we show in the following, is a particularly poignant aspect of ecological civilization, because while it indeed contains generalized guidelines for how to develop policies, laws, and technologies for the future, it also constitutes a much broader moral guide to proper civil behavior and attitude, all based on a specific interpretation of China's philosophical tradition that helps to strengthen a sense of national continuity. Sheila Jasanoff defines sociotechnical imaginaries as "collectively held, institutionally stabilized, and publicly performed visions of desirable futures, animated by shared understandings of forms of social life and social order attainable through, and supportive of, advances in science and technology" (Jasanoff, 2015a, p. 4). Eco-civilization, we argue, is a very good example of a state-initiated sociotechnical imaginary in which cultural and political-moral virtues constitute key components that are inseparable from technological, judicial, and political values.

Subsequently, we analyse what this imaginary looks like, how it is presented to the Chinese population and increasingly to the world, and, not least, how it constitutes a unique interpretation of traditional Chinese philosophy aimed at creating a convincing imaginary of the future. Our main sources of analysis are a combination of recently published government sponsored educational material and official documents, together with media representations going back to 2006, the first time eco-civilization was promoted in a newspaper by Pan Yue, then deputy director of China's State Environmental Protection Agency. We start with a short section on how the idea of an eco-civilized China and world relates to the Chinese government's ultimate goal of continued economic growth. We then move to our more detailed analysis of three aspects of eco-civilization that are crucial for understanding what this imaginary means and implies: firstly, how eco-civilization is grounded in contested interpretations of China's philosophical past; secondly, how science and technology are presented to the population as keys to achieving ecological civilization; and thirdly, which moral values eco-civilization projects onto environmental citizens and government officials expected to strive towards the ultimate goal of ecologically sustainable economic growth.

\section{Economic growth in an eco-civilized world}

Before moving to the details of how eco-civilization is constructed and communicated, it is necessary to establish how eco-civilization remains intimately connected to the government's aim of continued economic growth under the leadership of the Communist Party. In a detailed discourse analysis of key policy documents related to eco-civilization, Edwin Schmitt has clearly shown that while there are some specific examples where environmental protection is privileged over economic development, for instance in cases when it is necessary to control polluting industries, in general the commitment to economic growth in China is a fundamental feature of ecological civilization (Schmitt, 2016, pp. 74-111). A few Chinese articles on ecocivilization have tried to make the argument that China has a unique tradition of economic 
self-restraint that can also serve as a model to overcome contemporary consumerism created by Western philosophical tradition and industrial civilization (Pan, 2008). However, in the dominant versions of eco-civilization continued economic growth is never argued against, and no documents suggest radical alternative means of, for instance, redistributing wealth and slowing production in order to prevent further environmental degradation. This is also confirmed in one of the explicit statements about ecological civilization as a vision not merely for China but for the common global future. After his election for a second term as president of the International Union for the Conservation of Nature, former Minister of Education Mr. Zheng Xinsheng, emphasized in an interview that eco-civilization was meant to be a global vision built on the foundation of a culture of commerce. Eco-civilization was aimed at transforming the world but without changing the path of global capitalist economic development. Eco-civilization should not eliminate "commercial civilization" (shangye wenming 商业文明), according the Zheng, because “the two are mutually reinforcing, and ecological civilization evolves from the very basis of commercial civilization" (interview in Province in 2005, used a metaphor that has since become popular in numerous speeches about eco-civilization, precisely because it emphasizes the economic rationale for keeping the environment clean: "clear waters and lush mountains are gold and silver" (lüshui qingshan jiushi jinshan yinshan 绿水青山就是金山银山), meaning that they are invaluable assets.

In other words, at the abstract level ecological civilization is an imaginary that insists on the possibility of transgressing what others have termed the most fundamental double-bind of 21 st-century global capitalism, namely the chronic tension between economic development and human-ecological sustainability (Eriksen and Schober, 2016). In this way, ecocivilization is well adapted to the global capitalist order, and it does not suggest any radical turn towards slow and resilient growth combined with major redistributive measures, either at the global level or within China. At the same time, eco-civilization insists that Chinese philosophical traditions valued "ecological harmony" and that these can be revived in order to create a green future. This future will be essentially different from the so-called "Western black modernization", which is seen as a continuation of human-first ethical principles inherent in Western philosophy, and which, according to Pan, brought us all into the environmental mess we face today (Pan, 2006a, 2006b). In the officially sanctioned ecocivilized future, the world has by no means broken free from a growth-based economic system of production and trade. Instead, in Pan's reductionist and selective interpretation of tradition and philosophy, aiming at establishing complete harmony between China's past and Marxism, including Xi Jinping's visions for a eco-friendly future, it is argued that ecocivilization represents a more advanced state of human civilization. In other words, ecocivilization is compatible with the Chinese Communist Party's post-Mao version of "socialism with Chinese characteristics", but transcends it by elevating the value and power of nature while reducing human beings to a central rather than dominant role:

According to Western traditional philosophy, mankind is the most valuable part of the world while nature and other forms of life are targets for our domination and therefore have no value. Therefore, morality is only designed for man and there is no need to act morally towards nature or any other forms of life. This is the philosophical basis for the concept of man ruling nature in the industrial civilization. The ecological civilization, however, believes that value exists in both man and nature; nature is also endowed with the power to take the initiative; and all forms of life depend on nature, including mankind. Therefore, man must respect life and nature, as the earth is home to both. (Pan, 2006b) 
Western "traditional philosophy" is here presented as being in stark contrast with the ideals of eco-civilization, while a combination of theories of Marx and Engels and selected Chinese classical texts regarding mankind and nature are elevated, to the status of a philosophical basis for the eco-civilized imagined future, and further discussed in Pan's later publications (2015). Pan argues that eco-civilization constitutes an "advanced form of social harmony," thus emphasizing that eco-civilization is not merely a framework for policy- and law-making aimed at a more environmentally sustainable world, but just as much a vision with sociopolitical and moral dimensions.

In sum, eco-civilization is envisioned as a cultural ethic of complete harmony (hexie gongsheng 和谐共生) between humankind and nature, among human beings themselves, and in their relation to society (Pan, 2007). It serves as a state promoted imaginary of a Chinese socialist, and eventually global form of "civilization", built on growth, production, trade and a responsible way of dealing with natural resources. The way to achieve this future, according to the logic of eco-civilization, is through technological and scientific advancements, proper political planning and implementation, and by means of social control combined with the population's heightened environmental consciousness. As shown in the following section, it is based on a very specific interpretation of ancient Chinese texts.

\section{Constructing a Chinese eco-tradition}

Eco-civilization as an imaginary for a global future draws on reductionist and often biased, interpretations of philosophical and religious traditions in China's ancient past in order to make claims to a fundamental difference in the relationship between humankind and nature, and between Western and Chinese thought. The philosophical basis for the imaginary was mainly developed by Pan Yue over time, drawing from ideas promoted by scholars in China already in the 1980s (Marinelli, 2018; Schmitt, 2016, pp. 77-82), His ideas have never attained a strict, precise or coherent theoretical form, but have rather come to constitutes a polemic basis for later arguments in favor of a specific Chinese eco-tradition. Pan and other advocates of eco-civilization assert that Chinese tradition is ecocentric, endorsing ideas about an intrinsic harmony between humankind and nature. In stark contradiction, they argue, Western tradition is essentially anthropocentric, placing humans in a dominant position vis-àvis nature, eventually bringing the world into the "black" and unsustainable development prompted by industrial civilization. They further maintain that Western civilization long had the opportunity to develop an ecological vision for the future, but failed to do so precisely because of its inherent anthropocentrism (Pan, 2003, 2006b; Jiang, 2013). China, on the other hand, is now able to offer an alternative philosophical basis for an eco-friendly future, due to what Pan and others regard as a strong eco-tradition firmly rooted in ancient Chinese ethical values with universal significance:

Environmental problems in China have a particular significance for global sustainable development; China's history is old, and her culture is grand; China's environmental culture will broadly absorb the outstanding achievements of world environmental culture and on this basis will offer to the peoples of the world a unique style suitable for new times to achieve common goals. (Pan, 2003)

Notions of culture, tradition, national identity, and recent experiences of environmental risks are woven together in a polemic attempt to argue that the key to the global future lies in a revival of China's past ecological philosophy. 
The question remains how central to China's tradition - or rather traditions - such ideas about harmony between humankind and nature actually are, in particular given what historical research has long disclosed regarding the considerable environmental destruction during China's pre-modern past (Elvin, 2004; Marks, 2012). Ecological ethics in China's philosophical and religious traditions were debated in a series of academic conferences at Harvard University from 1996 to 1998 that engaged Chinese and American scholars working on the relationship between religion and ecology, resulting in several major publications (see Tucker and Williams, 1997; Tucker and Berthrong, 1998; Girardot, Miller, and Liu 2001). This period therefore became a turning point in the academic understanding of Chinese philosophies of ecology, and interestingly many of the perspectives expressed in these volumes on ecological philosophy within Daoism, Buddhism and, most prominently, Confucianism, are clearly recognizable also in Pan Yue's later expositions from 2003 onwards when he started to develop the theoretical basis for China's imaginary of ecocivilization.

The essential part of Pan Yue's assertions about an intrinsic harmony between humankind and nature in Confucian philosophy is developed from passages in Confucian texts on the philosophical concept of the "unity of heaven and man" (tian ren he yi 天人合 一). Heaven (tian 天) in ancient China represented an ultimate form of authority that was interpreted differently in different periods and by different people. It could indicate personal authority, but also highly impersonal forms of power related to the order of the natural world; for others, it was correlated with social order and human ethics (Graham, 1989, pp. 1, 197, 238-244). However, implicit in all of Pan's writings on eco-civilization and China's ecotradition, and in line with many of the articles in the Harvard series, is the identification of heaven/tian with Nature. This approach is applied by Pan in order to translate and interpret ancient Confucianism into a modern prescription for a future global eco-civilization: "Human affairs must adhere to the will of Nature (tian). [Humans] must take the laws of Nature and transform them into human rules, must follow the principles of Nature, and only then will the state be prosperous and the people live in peace" (Pan, 2003). Pan's theory of harmony between humankind and Nature directs attention to the innate ethical nature (dexing 德性) of human beings. Ignoring empirical evidence from the past, Pan argues that proper ethical conduct in line with humans' innate ethical nature prescribed by Confucian philosophy, will ensure care and benevolence for nature, and thus form the basis for ecologically sound behavior (Pan, 2006a, 2008). Chinese eco-tradition, Pan Yue insists, has not only taught the philosophy of eco-ethics long before the time of Confucius, but also the practice of environmental protection:

Already early on China had its own "environmental culture" (huanjing wenhua 环境文化). During the Xia dynasty 4000 years ago, felling trees in spring was prohibited, as was catching fish, killing young wild animals and collecting bird eggs in summer. During the Zhou dynasty 3000 years ago, hunting for animals, catching birds, fishing, logging, and burning fields were strictly regulated according to the climate and season. During the Qin dynasty 2000 years ago, harvesting young sprouts and catching young wild animals was strictly prohibited, and it was forbidden to kill fish and turtles with poison. For every dynasty and every epoch there were explicit laws and prohibitions to protect the environment. (Pan, 2003)

In all of his writings, Pan highlights examples of regulations that favor protection of natural resources, but he seems unaware of scholarship that has long demonstrated considerable levels of environmental degradation caused by demographic pressure, proto-industry and 
quest for resources and energy in pre-modern China, and in spite of regulations and claims to eco-ethics in Chinese philosophy (e.g., Elvin, 1993, 2004; Elvin and Liu, 1998).

Although Pan mainly draws on Confucianist texts and ideas to create a specific

303

304

305

306

307

308

309

310

311

312

313

314

315

316

317

318

319

320

321

322

323

324

325

326

327

328

329

330

331

332

333

334

335

336

337

338

339

340

341

342

343

344

345

346

347

348

349
Chinese version of traditional eco-culture, he also seeks to integrate this with both Daoist and Buddhist elements. In Daoism, according to Pan, heaven/tian does not represent a moral or political authority, but rather, “the Way (dao 道) is modeled on nature (ziran 自然)" and the loftiest principle is humanity's respect for the laws of nature (Pan, 2003). Similarly, Pan claims, Buddhism teaches that Buddha nature (foxing 佛性) is the unity and the essence of all things in the universe. It implies that all living things are equal and that all have the right to exist, affirming an intrinsically ecocentric view of humankind and nature (Pan, 2003, 2006a). To Pan, Chan Buddhism in particular represents a distinct Chinese interpretation of Buddhist philosophy, one that has been influenced by Confucian ethics, Chinese philosophical ideas of unity between heaven and man, and the Daoist ideal of the simplicity of life (Pan, 2008).

How, then, does Pan Yue manage to converge these very different traditions with regard to epistemology, ethics, and humanity's relation with nature in ancient China? He devises a notion that all three traditions share one principle, or vision, of humanity's relationship with the environment referred to as "allotment" ( $d u$ 度). The concept of allotment is conveyed in ancient philosophical and religious texts, represented in Chinese politics, practiced in the everyday lives of Chinese people, and condensed in the expression of Chinese “ecological wisdom” (shengtai zhihui 生态智慧) (Pan, 2008). In this way, Pan constructs and envisions a common ecological and ecocentric wisdom that he claims runs through Chinese tradition and is waiting to be revived in the contemporary age. These ideas have found resonance among policy makers in China, as discussed above, as well as among some academics. Internationally, Pan's claims to a unique Chinese eco-tradition have often been viewed positively, and this scholarly affirmation has been fed back into the Chinese discourse, as seen, for example, in Chinese references to supportive statements from scholars like Tu Weiming (Harvard University and Peking University), Homes Rolston (Colorado State University), Roy Morrison (Southern New Hampshire University), and Alexander Romanov (Russian Academy of Science).

However, this discourse on China's eco-tradition has its critics. In China, Professor of Environmental History, Wang Lihua at Nankai University, approves of Pan's assumption that philosophical and ethical principles for a sustainable environment are intrinsic to Chinese tradition, but he questions the assumed correlation between theory and practice. He recognizes the devastating environmental destruction caused by humans in China's past and ascribes the incongruity between principles and historical practice to the loftiness of philosophical writing that had no practical implications for people's lives. Contradicting Pan, Wang argues further that regulations and restrictions on the harvesting of natural resources in China's early history were instituted to benefit the ruling elite and not for environmental purposes (Wang, 2013). The sinologist Heiner Roetz has been even more explicitly critical of Tu Weiming, Pan, and others' selective and biased reading of passages from Confucian texts. Roetz has shown that traditional cosmological philosophy and practice in China were in fact largely anthropocentric (possibly with the exception of Daoist texts), promoting a worldview where humankind took charge of nature and mended its deficiencies (Roetz, 2013). Likewise, Buddhologist and art historian Henrik H. Sørensen questions Pan's portrayal of Buddhist epistemology and argues that Buddhism is primarily a spiritual movement which has frequently displayed a utilitarian approach to nature (Sørensen, 2013, pp. 90-96).

In sum, it is safe to conclude that the imaginary of eco-civilization is built upon a selective, reductionist and contested interpretation of ancient philosophical traditions and of China's past that contradicts evidence about massive environmental destruction throughout Chinese history. The officially sanctioned version of China's ecological tradition builds on 
Pan's assertions of ecocentrism in Chinese philosophy, and indicates that ancient farming practices were in harmony with ecological principles because of China's ancient ecotradition, for which there is little evidence. This vision of China's eco-tradition buttresses the government's environmental policies and promotes, at the same time, national pride in ancient Chinese tradition and support for socialism, as defined by the Communist Party. It also promotes certain values of science and technology that we analyse in more detail in the following section.

\section{The green engine: Science and technology in the imaginary of eco-civilization}

Science and technology constitute an inherent part of any public discourse on a sociotechnical imaginary. In its early phase, eco-civilization was formulated mainly as cultural principles and ethics about human beings and nature, and there was limited discursive space for science and technology. However, gradually and not least after the endorsement of President Xi Jinping, science and technology have become major components of the vision, and the driving force towards what is perceived as "the green future." In this way, ecocivilization has developed from a largely philosophical endeavour into a full-fledged sociotechnical imaginary with political backing.

Just as the philosophical vision of eco-civilization is articulated against the backdrop of industrial civilization, the discussion of science and technology begins with a critical reflection on their double-edged impact on modernization. Here it is recognized that China's own economic development, as part of the long-term historical processes of industrialization, is to blame for many environmental problems, and there is no longer mentioning of specific "Western" forms of industrialization:
Especially since the industrial revolution, scientific and technological advancements have sustained industrialization and created enormous material wealth, but have also caused the rapid exhaustion of natural resources and the gradual deterioration of the ecological environment, which directly threatens the survival and development of humankind. (Ma, 2012)

According to Ma, a top official from the Ministry of Science and Technology, the contradiction between traditional industrial civilization and the capacity of the environment is now so extreme that substantial innovative breakthroughs in science and technology are urgently needed. An opinion piece carried by the Chinese newspaper Science \& Technology Daily in 2015 invoked the metaphor of a green engine to portray the ideal relationship between scientific and technological innovation and eco-civilization (Shen, 2015). On the one hand, innovations would provide the necessary "motor power" for the building of ecocivilization, which in itself is metaphorically presented as a machine or an automobile. On the other hand, such innovations would have to be "green," even though it is acknowledged that any "engine" would inevitably have its "black" side with negative environmental consequences. In other words, scientific and technological innovations - rather than a fundamental change of the world economic system or a redistribution of resources - are seen as key forces in the development of an eco-civilization.

Some of the more recent documents on eco-civilization even highlight specific technologies that are seen to be compatible with the imaginary of eco-civilization, distinguishing between "black" and "green" technologies. Bai Chunli, the president of the Chinese Academy of Sciences, for instance, introduced 15 Strategic Priority Research Programs, six of which were explicitly described as being closely related to the building of 
eco-civilization (Bai, 2014). This included, for instance, technologies for cleaner and more and the control of air pollution. Also, the general Guideline on Accelerating the Development of Ecological Civilization, issued by the Central Committee of the Communist Party of China and the State Council in late April 2015, emphasized the leading role of sci-tech innovations as the primary means to achieve eco-civilization (Xinhua News Agency, 2015). In other words, technologies used in the processes of industrialization produced the environmental problems that China and the world are facing, and technologies are now also regarded as the main tool to solve the problems.

Under the headline of "promoting scientific and technological innovations," the guideline highlight a number of key areas in which scientific and technological research should be strengthened, such as energy saving, resource recycling, new energy development, pollution control, and ecological restoration, all considered to be "green". In fact, it may be argued that the imaginary of eco-civilization not only accommodates a smaller sector of the vast sci-tech world but advocates a paradigm shift in science per se, and in particular in how Chinese society is expected to perceive and relate to technologies. It points to a new era of worldwide sci-tech and new forms of industrial revolutions, providing both challenges and opportunities to green and sustainable developments (see e.g., Bai, 2014; Shen, 2015). The official Party mouthpiece People's Daily, for instance, published four successive editorials on eco-civilization, the second of which focused on the green transition as a new form of modernization and civilization:

For the first time, the guideline raises the concept of "greenization" (lüsehua 绿色化) and juxtaposes it with new types of industrialization, urbanization, informatization, and agricultural modernization. From the "new Four Modernizations" to the "new Five Modernizations," is a major theoretical innovation. [... ] To a certain extent, the process of modernization is the transition of civilizations, including the transition from fossil fuels to renewable energy, from high-carbon economy to low-carbon economy, from industrial civilization to eco-civilization. (People's Daily, 2015a, emphasis added)

Clearly, the imaginary of eco-civilization is by no means an abandonment of the official Chinese vision of socialist modernization as building on state controlled economic growth and integration into the global capitalist market economy that has been dominant since the late 1970s. Rather, it redefines these political ideals and practices in light of a new imaginary path of transition in civilization. For instance, in a lecture by Professor in environmental science, Qian Yi, from Tsinghua University's Centre for Ecological Civilization in April 2018, a simple Marxist inspired interpretation of a history of civilizations was outlined. The lecture was introduced to the audience as a means of "explaining to the foreign participants" in the seminar what eco-civilization was really meant to be. Qian Yi argued that humans have gone through three stages of civilization: primitive civilization characterized by fears of nature, agricultural civilization where people relied on nature, and industrial civilization where the aim was to conquer nature. The coming stage of evolution, she claimed, was "the advanced form of human civilization" called eco-civilization. This was presented as an indisputable scientific outline of history to an audience of university professors and scholars from Norway and China. It was entirely in line with the official representation of eco-civilization that adds in some more concrete details (to the Chinese rather than the global audience) that in the $20^{\text {th }}$ century, the Communist Party took China through the early socialist period of heavy stateowned industrial development and economic isolation during Mao's tenure, and continued 
integration into the global market and rapid privatization of production during Deng's tenure. The very same Party will, according to the imaginary, now lead China towards a form of new socialist modernity - "a new era" - in which economic growth, environmental protection, and global integration amalgamate into a complete harmony. Following this logic, it makes sense that the government implements a range of new environmental laws and regulations while still insisting that a growth rate of more than 6 per cent every year is sustainable and desirable.

This vision of the future also has implications for how citizens and officials are expected to live, and it is presented to the public as a natural course of evolution of Chinese socialism, building on the combination of a strong national identity and unquestioned leadership by a Communist Party and charge and in motion. In the public representation of eco-civilization, older socialist models are therefore revived and injected with new ecological meanings in line with the imaginary of the future, as we continue to show in the following section.

\section{Old socialist models, new eco-civilized public}

The idea of ecological-civilization has evolved into a full-fledged socio-technical imaginary with concrete policy implications and is no longer perceived by the government as an abstract ideal, but rather as a plausible vision which can be achieved in practice. Therefore, the official discourse now also constructs and incorporates for the public illuminating examples that are congruent with the values of ecological civilization and relate them to real-life circumstances. This discursive move is used to enhance the legitimacy of the imaginary and mobilize the general public to engage with a promising future by addressing questions such as, who are the best civil practitioners of this new civilization that can serve as exemplars for others to follow, and what will an ecologically civilized official or citizen look like.

In early December 2017, seven inspirational environmental leaders won the Champions of the Earth award, the United Nations' top environmental honor. Three came from China: Chairman of Elion Resources Group, Mr. Wang Wenbiao won for "a lifetime of leadership in green industry"; bike-sharing startup Mobike for "exploring market-driven solutions to air pollution and climate change"; and Saihanba Afforestation Community for "transforming degraded land into a lush paradise" (Champions of Earth, 2017). For Chinese official media, garnering nearly half of the awards was a demonstration of China's "global leadership in environmental governance" (China Daily, 2017b) as "China contributes wisdom and a course of action for global eco-civilization construction, and 'Beautiful China' (meili Zhongguo 美丽中国) wins applause from all over the world” (Liu and Li, 2017). However, by far the most media attention in China has been devoted to Saihanba, because already months before the UN awards, this state-owned enterprise had become a media symbol of how China transforms older socialist models into visionary examples of a socialist eco-civilization. Thus, the case of Saihanba is a good example of how not only ancient Chinese philosophy is used to breathe life into the imaginary of eco-civilization, but also how China's socialist legacy is revitalized and accommodated to this vision.

Saihanba is a national forest park covering 75,000 hectares at the southern edge of the Inner Mongolia Autonomous Region. It was established in 1962 with the aim of reforesting an area that had become a barren desert due to large-scale land reclamations in the 19th century and the cause of sandstorms. As part of a larger propaganda campaign called "Green Development, Green Life” (lüse fazhan, lüse shenghuo 绿色发展, 绿色生活), launched prior to the opening of the 19th CPC National Congress in 2017, more than 80 reporters and photographers from 19 national and local news media went to Saihanba to conduct interviews. 
In the subsequent months, hundreds of stories about this afforestation community were posted on media outlets with headlines highlighting Xi Jinping's praise of Saihanba for "setting a great example in China's pursuit of ecological progress" (China Daily, 2017a) and "making the great motherland more beautiful" (People's Daily, 2017a). Taking People's Daily as example, this central mouthpiece carried more than forty news stories and opinion pieces about Saihanba in 2017, including several editorials. From central to provincial and local media platforms, Saihanba became the primary model and exemplary of the imaginary of ecocivilization in a society where exemplarity has long been regarded as a highly powerful transformative moral force (Bakken, 2000). Due to its previous status as a longstanding socialist model, Saihanba became an exemplary model of how "socialism with Chinese characteristics" was able to project a new eco-civilized future:

511

512

513

514

515

516

517

518

519

520

521

522

523

524

525

526

527

528

529

530

531

532

533

534

535

536

537

538

539

540

541

542

543

544

545

546

547

548

In the past 55 years, the foresters at Saihanba, generation after generation, commit to their mission and work very hard amid grave difficulties. [...] Looking at the 75,000 hectares of immerse forests from the satellite cloud pictures, this vast area of green is just like an eagle spreading its wings wide, firmly grasping the southern edge of the Otindag sandy land in Inner Mongolia [...] a green Great Wall, a shield against sand, a guardian of water sources for Beijing-Tianjin-Hebei region and the north of China.

Shouldering the historical mission and political responsibility of restoring and protecting the environment, people at Saihanba have created a green miracle in the history of the ecological construction in sandy alpine regions, a well-deserved exemplar of the building of eco-civilization, and a vivid illustration of the important thought "clear waters and lush mountains are gold and silver" that President Xi Jinping has emphasized time and again. (Wu, Liu and Shi, 2017)

In the promotion of Saihanba as a model, there is again a strong focus on the significance of science and technology as "the golden key to the breakthrough of afforestation" (Shi, 2017), but at least as important is the emphasis on how the Saihanba "spirit" constitutes a special moral asset and is a symbol of lessons to be learned for officials and citizens in the new era of ecological civilization:

Decades ago, the first generation of Saihanba people came to this deserted wasteland with the passion and enthusiasm to make their contributions to the motherland. They drank snow or rain water, ate steamed corn breads and pickles, walked against strong wind and blizzards, slept on stone beds with straw. Due to their fearless spirit, the Saihanba people conquered all the difficulties and finally created this immortal green monument. (Guangming Daily, 2017).

As another editorial in the People's Daily put it, "Saihanba is visually green but its spirit is red" and it is "the sweet fruit of a long-term struggle of both cadres and masses dedicated to the Party and the country's calling" (People's Daily, 2017b). This reinterpretation of the legacy of the socialist past serves current ideological needs, and articles on eco-civilization therefore calls for "more Saihanbas" and "Saihanba peoples" (Guangming Daily, 2017). The example is set for others to emulate because, argues the author of an opinion piece in People's Daily, "everybody is actually the player of the notes of ecological civilization. We might not be able to be 'ecological guardians' like Saihanba people who keep planting trees and 
protecting the forest, but we could become action takers who cherish ecology, preserve resources, and protect the environment" $(\mathrm{Li}, 2017)$.

Saihanba set an example not only for officials but also the ordinary citizens. How then

Figure 1: "Practice a green way of living, carry forward the governance of water and air." Source: Hangzhou Environmental Protection Bureau 2015.

Figure 1 is representative of many images of the ideal eco-civilized future produced for public dissemination. It is a cover from a 2015 book that introduces, to readers in Zhejiang Province, a range of environmental policies and goals based on popularized scientific presentations of key environmental problems, such as polluted water, soil and air. In this utopian illustration of the eco-civilized future, a middle-class, happy, young family with two children — a boy and a girl— lives in a green world with perfect blue skies. Energy is provided by solar panels and windmills, animals are domesticated but not restrained, a bicycle is close at hand while a green car is available in the background, and a sorting system for household garbage is in place. The father in the picture might well be one of the many local officials in China who are expected to change their behaviour and prioritizations now that economic growth is not the only top goal for the country and the one-child policy (that used to be part of the evaluation of cadre performance) has been abandoned. The ultimate goal is now eco-civilization and Figure 2 below illustrates what the state therefore now expects from the cadre with ambitions to climb the promotional ladder. 


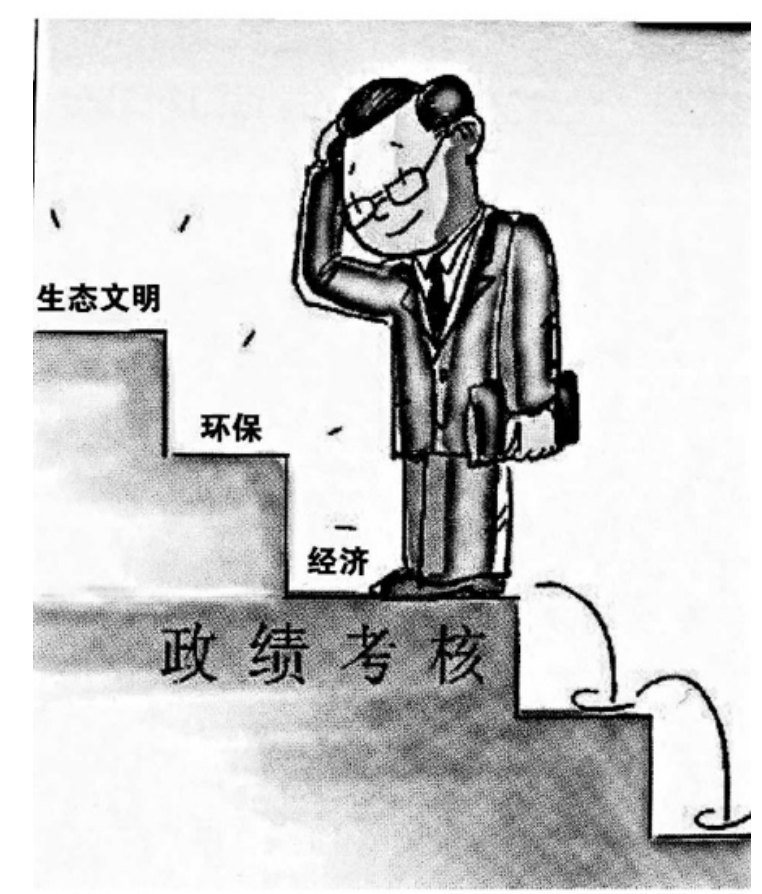

Figure 2. Title of image: “Assessment of achievements"

Source: Educational Center of Hangzhou City Environmental Protection Bureau (2014), 34.

The caption on the staircase reads "Assessment of achievements," and the first step on the cadre's ladder indicates the usual and well-known targets set for the local economy (jingji 经 济). However, the cadre (typically represented as a man in formal office outfit) seems to be pondering how to now also achieve the target on the next step, which is environmental protection (huanbao 环保). He smiles, probably in appreciation of the fact that all local governments are expected to pay much more attention to the local environment than was previous the case, but his eye is not yet on the top stair. Still beyond his view, the final step represents ecological civilization, the ultimate amalgamation of economy and environmental protection that the official is supposed to achieve (e.g. Heberer and Senz 2011). Put into words, an editorial in People's Daily (6 June 2015) plainly explicates what the government expects from each leading cadre:

Every leading cadre has to make eco-civilization a major political task. The results of eco-civilization will be the major criteria for evaluating the quality of modernization and of political ability. If we can take ecological advantages and turn them into economic advantages, if we can take ecological capital and turn it into developmental capital, and if we let the development of green industry lead advancements in economic transformation, then we can turn green development into an entirely new form of national strength and an advantage in international competition. (People's Daily, 2015b) 
This is no small task, but cadres should expect to receive help from eco-civilized citizens, especially from the young generation who is now the main target of a large number of moral eco-civilization campaigns.

In one of numerous books for a young readership (Figure 3), we meet again the ideal middle-class Chinese family. The couple and their daughter are about to step into their car. The father is dressed in a suit and tie, suggesting that he is a white-collar worker on his way to work, and the mother is inconveniently wearing a long dress, certainly not on her way to do any form of manual labor. The child, carrying her school backpack, asks: "Mummy, can we take the bus instead? The teacher says that if we all drive cars, we won't have blue skies." Looking slightly taken aback, the mother comments that her daughter really understands things, so "from now on we will drive the car one day less every week, okay?"

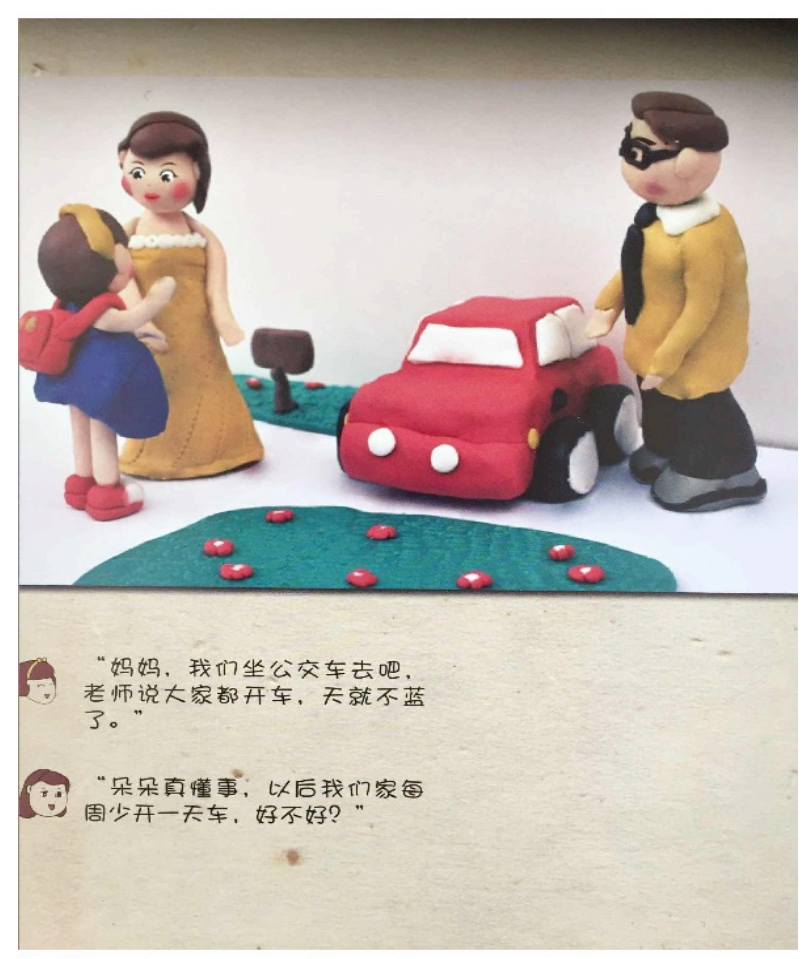

Figure 3. Source: Educational Center of Hangzhou City Environmental Protection Bureau (2012), 4.

Visualized educational campaigns like this one, exposing one exemplary modern nuclear middle-class family after the other, are supplemented by media reports and articles explaining the aim of eco-civilization as something much more far-reaching than merely a change of laws, policies, and technological innovations. It involves "a greening of people's ways of life," a considerable "rise of environmental consciousness" among all citizens, and changing practices related to consumption and production (People's Daily, 2015a). Ecocivilization is remaking the socialist models long taught in Chinese schools (Hansen, 2015; Reed, 1995) and promoted in public media (Bakken 2005) by setting focus on environmental issues. Through the established PRC process of exemplarity, it propagates the vision that the Communist Party, having recognized that the country faces profound environmental problems, now foresees a brighter future in which economic growth have supported an expanding middle class, and where individuals, communities and political leadership alike take responsibility for ensuring also an environmentally sustainable world.

\section{Conclusion}


637 Ecological civilization is a governmental framework for developing China's environmental

638 laws and policies, supporting technological innovations that are seen as essential to solve the country's enduring and now well-known threats of environmental degradation without hampering economic growth. As we have argued in this article, it is more than that. It is an imaginary of the global future, and it is the Communist Party's promise to the Chinese population. It holds that under the continued leadership of the Party, it is possible to make a historical move from one kind of "civilization" to another.

Eco-civilization was, at its outset, first a rather incoherent, self-contradictory and partial interpretation of China's eco-tradition, and a project aimed only at local Chinese readership and society. It was readily adopted by the highest political leadership as an ideology conveniently planted in a nationalist interpretation of the philosophical past. By invoking a Chinese trajectory of traditional eco-philosophy and a reinterpretation of the socialist legacy, the Party was able to develop it into an overall framework for its new environmental policies and goals that had a decided nationalist edge to it. It has now become a political project with bearings for laws and policies at central and local levels, and with consequences for how socialist and moralist campaigns are aimed at broad segments of society. It is an imaginary of a utopian harmonious world in which production and consumption continue to grow, where technology and science have solved the basic problems of pollution and environmental degradation, and in which the Chinese population lives as middle-class citizens under the leadership of the Communist Party.

Eco-civilization also enjoys increasing global appeal, probably because it meets little competition from other global environmental visions for the future. The organization Millennium Alliance for Humanity and the Biosphere expressed a widely shared opinion when it in 2017 stated that "capitalising on failures of U.S. leadership, China is emerging as a potential 'great green power' of the 21 st century" (Cribb, 2017). Eco-civilization is presented in English on the UN Environment Program website as "an ethical morality and ideology which realizes harmonious co-existence and sustainable development both among people and between them and nature and society, reflecting the progress of civilization" (Zhu, 2016), and the term is used rather uncritically by an independent think-tank "Toward Ecological Civilization" (http://ecociv.org/\#who), established in 2015 by American academics involved in the study of traditional eco-philosophical trajectories. It has been called "the new enlightenment" by scholar-activist David Korten (2017), and more and more civil organizations seem to join in the appreciation of a powerful state and government that dares to formulate lofty ideals and visions for an ecologically sustainable future.

There is sufficient evidence to argue that this socio-technical imaginary has come to constitute a broader ideological framework for the government's much needed strengthened policies related to environmental protection and climate change. It has positive implications for environmental governance in local areas of China, and for enhancing the population's awareness of the environmental challenge. It has also helped to provide the Chinese political leadership with a more positive global image as a responsible climate actor. At the same time, it is by no means a binding political plan, and the documents and representations we have analyzed provide no basis for claiming that eco-civilization is likely to result in profoundly new practices of, for instance, resource extraction, investments, or redistribution of resources. It does not imply an ecological revolution of any kind, and it largely ignores the environmental risks involved in continued global growth dependency. It is first of all an attempt to promote a view of the future in which the existent global capitalist economic system remains intact, but is injected with a firm dose of environmental responsibility on the part of citizens, states and economic actors. It may also be regarded as a revised form of the Communist Party's idea of "socialism with Chinese characteristics". It adds to the aim of 
economic growth and leadership of the Party, the new goal of achieving a safe and sustainable natural environment for human beings (other species rarely mentioned), and it constructs a philosophical basis for the imaginary that is inherently Chinese with a nationalist twist. civilization needs to be better understood and monitored as it evolves, for instance, in relation to practices of new large-scale infrastructure projects abroad, such as the Belt and Road

692 Initiative. The article has first of all focused on how official authors and media articulate the imaginary of eco-civilization, and it therefore also leaves open the question of how the Chinese population receive and evaluate this imaginary, if they accept it as a vision for the future or regard it as, for instance, a set of empty slogans. Finally, it calls for more research into alternative, or possibly even counter, narratives of eco-civilization and the environmental future of China, considering the fact that the $\mathrm{CCP}$ and government are persistently portrayed in official discourse in praising terms as the architect of eco-civilization, while especially local governments and official are often the targets of public environmental protests and criticism. 
Ahlers, Anna L., and Mette Halskov Hansen. 2017. “Air Pollution: How Will China Win Its Self-Declared War against It?" In Routledge Handbook of China's Environmental Policy, edited by Eva Sternfeld, 83-96. London: Routledge.

Ahlers, Anna L., and Yongdong Shen. 2018. "Breathe Easy? Local Nuances of Authoritarian Environmentalism in China's Battle against Air Pollution.” The China Quarterly, vol. 234, June, 299-319.

Bai, Chunli 白春礼. 2014. “推进科技创新 建设生态文明 (Advancing Sci-tech Innovations, Building Ecological Civilization).”Study Times 学习时报, June 2, 10.

Bakken, Børge. 2000. The Exemplary Society: Human Improvement, Social Control, and the Dangers of Modernity in China. Oxford: Oxford University Press.

Cai, Peter. 2017. “Understanding China's Belt and Road Initiative.” Report. Sydney: The Lowy Institute for International Policy.

Champions of Earth. 2017. "UN Environment Reveals the 2017 Champions of the Earth." Updated 05.12.2017. http://web.unep.org/championsofearth/press-release/unenvironment-reveals-2017-champions-earth (accessed 25.01.2018).

China Daily. 2012. "Full Text of Hu's Report at 18th Party Congress." Updated 18.11.2012. http://www.chinadaily.com.cn/china/2012cpc/2012-11/18/content 15939493.htm (accessed 20.02.2018).

- 2015. "Everyone Responsible for Creating a Healthy Ecological Civilization." Updated 07.05.2015. http://www.chinadaily.com.cn/opinion/201505/07/content 20642952.htm (accessed 20.02.2018). . 2017a. "Xi Stresses Efforts to Build Ecological Civilization.” Updated 28.08.2017. http://www.chinadaily.com.cn/china/xismoments/2017-08/28/content_31318415.htm (accessed 20.02.2018).

- 2017b. "China Shows Global Leadership in Environmental Governance." Updated 06.12.2017. https://chinadailyasia.com/articles/137/63/161/1512532083441.html (accessed 20.02.2018).

Cribb, Julian. 2017. "Green China: In Pursuit of Rebuilding as 'an Ecological Civilization'.” Updated 13.06.2017. https://mahb.stanford.edu/blog/green-china/ (accessed 26.09.2018).

Delman, Jørgen. 2018. "Ecological Civilization Politics and Governance in Hangzhou: New Pathways to Green Urban Development?" The Asia-Pacific Journal: Japan Focus, vol. 16 , no. $17,1-21$.

Educational Center of Hangzhou City Environmental Protection Bureau. 2012. “环保生活每 一天 (Every Day of Environmental Protection).” Hangzhou: Hangzhou City Environmental Protection Bureau.

—. 2014. “向污染宣战 (Declaring War on Pollution).” Hangzhou: Hangzhou City Environmental Protection Bureau.

Elvin, Mark. 2004. Retreat of the Elephants: An Environmental History of China. New Haven: Yale University Press.

Elvin, Mark, and Liu Ts'ui-jung (eds.). 1998. Sediments of Time: Environment and Society in Chinese History. Cambridge and New York: Cambridge University Press.

Eriksen, Thomas Hylland, and Elisabeth Schober. 2018. "Economies of Growth or Ecologies of Survival?" Ethnos, vol. 88, no. 3, 415-422.

Geall, Sam. 2015. "Interpreting Ecological Civilization" part 1-3. Chinadialogue. https://www.chinadialogue.net/article/show/single/en/8018-Interpreting-ecologicalcivilisation-part-one- (accessed 18.07.2018) 
Girardot, N. J., James Miller, and Xiaogan Liu (eds.). 2001. Daoism and Ecology: Ways within a Cosmic Landscape. Cambridge, MA: Harvard University Press.

Graham, Angus C. 1989. Disputers of the Tao. Chicago and La Salle, IL: Open Court. Guangming Daily 光明日报. 2017. “美丽中国呼唤更多的“塞罕坝” 人 (Beautiful China Calls for More 'Saihanba' People).” December 6, 1.

Hansen, Mette Halskov. 2015. Educating the Chinese Individual: Life in a Rural High School. Seattle: University of Washington Press. The China Quarterly, vol. 234, June, pp. 320-339

Hansen, Mette Halskov and Zhaohui Liu. 2018. "Air Pollution and Grassroots Echoes of 'Ecological Civilization' in Rural China”.

Heurtebise, Jean-Yves. 2017. "Sustainability and Ecological Civilization in the Age of Anthropocene: An Epistemological Analysis of the Psychosocial and 'Culturalist' Interpretations of Global Environmental Risks.” Sustainability 9(8):1331. https://doi.org/10.3390/su9081331

Jasanoff, Sheila. 2015a. "Future Imperfect: Science, Technology, and the Imaginations of Modernity." In Dreamscapes of Modernity: Sociotechnical Imaginaries and the Fabrication of Power, edited by Sheila Jasanoff and Sang-Hyun Kim, 1-34. Chicago: The University of Chicago Press. . 2015b. "Imagined and Invented Worlds." In Dreamscapes of Modernity: Sociotechnical Imaginaries and the Fabrication of Power, edited by Sheila Jasanoff and Sang-Hyun Kim, 321-43. Chicago, IL: University of Chicago Press.

Jiang, Zehui 江泽慧. 2013. “弘扬生态文化 推进生态文明 建设美丽中国 (Promote ecological culture, endorse ecological civilization, build beautiful China)." People's Daily 人民日报. January 11,7 .

Korten, David. 2017. "Ecological Civilization and the New Enlightenment." Tikkunn, Volume 32, Number 4 (Fall): 17-24.

Kostka, Genia, and Jonas Nahm. 2017. "Central-Local Relations: Recentralization and Environmental Governance in China." The China Quarterly, vol 231, September, 567582.

Li, Bin 李斌. 2017. “大家都来做种树者 (Everyone Comes to be Tree Planters).” People’s Daily 人民日报. August 5, 4 .

Liu, Yi 刘毅, and Li, Zhiwei 李志伟. 2017. ““美丽中国”赢得世界掌声 ('Beautiful China' Wins the World's Applause).”People's Daily 人民日报, December 7, 3.

Ma, Yanhe 马燕合. 2012. “重视科技创新 支撑生态文明建设 (Stressing Sci-tech Innovations, Sustaining the Construction of Ecological Civilization).” Science \& Technology Daily 科技日报, April 23, 1 .

Marinelli, Maurizio. 2018. "How to Build a 'Beautiful China' in the Anthropocene. The Political Discourse and the Intellectual Debate on Ecological Civilization." Journal of Chinese Political Science, vol. 23, no. 3, 365-386.

Marks, Robert. 2012. China: An Environmental History. Lanham, Boulder, New York, London: Rowman \& Littlefield.

Messner, Angelika C. "Transforming Chinese Hearts, Minds, and Bodies in the Name of Progress, Civility, and Civilization." In Civilizing Emotions: Concepts in NineteenthCentury Asia and Europe, edited by Margrit Pernau, Helge Jordheim, Emmanuelle Saada, Christian Bailey, Einar Wigen, et al., 231-249. Oxford: Oxford University Press.

Pan, Yue 潘岳. 2003. “环境文化与民族复兴 (Environmental Culture and National Revival)." Beijing: Ministry of Ecology and Environment of the People's Republic of China, October 28. 
http://www.mee.gov.cn/gkml/sthjbgw/qt/200910/t20091030_180661.htm (accessed 26.09.2018). 2006a. “生态和谐观：构建社会主义生态文明 (Perspectives on Ecological Harmony: Constructing Socialist Ecological Civilization.” 21st Century Business Herald 21 世纪经济报道, October 9. http://finance.sina.com.cn/review/20061001/22132961402.shtml (accessed 26.09.2018).

2006b. "Evolution of an Ecological Civilization." Beijing Review, November 9, updated December 15. http://www.bjreview.com.cn/expert/txt/200612/15/content 50890.htm. (accessed 26.09.2018). . 2007. “生态文明将促进中国特色社会主义建设 (Ecological Civilization Will Promote the Building of Socialism with Chinese Characteristics)." China.Com.Cn. October 23. http://www.china.com.cn/policy/txt/2007-10/23/content 9108996.htm (accessed 26.09.2018). . 2008. “中华传统与生态文明 (Chinese Tradition and Ecological Civilization).” Renminwang 人民网, December 15. http://env.people.com.cn/GB/8517913.html (accessed 26.09.2018). . 2015. “马克思主义生态观与生态文明 (Marxist view on ecology, and ecological civilization).” Study Times 学习时报, July 13, 8.

Pang, Qinghui 庞清辉, Pan, Linlin 潘林林, and Zhao, Yijing 赵一静. 2016. “生态文明理念 如何走向世界-专访 IUCN 章新胜 (Taking the Idea of Ecological Civilization into the World: An Interview with Zhang Xinsheng from IUCN)." Xinhua News. September 29. http://xhpfm.mobile.zhongguowangshi.com:8091/v210/newshare/1177400?channel (accessed 12.02.2018).

People’s Daily 人民日报. 2015a. “推动生产生活的绿色转型 (Promoting the Green Transition in Production and Life).” May 7, 1.

. 2015b. “抓好生态文明建设这项政治任务 (Concentrating on the Political Task of Constructing Ecological Civilization).” May 6, 1.

- 2017a. “把伟大祖国建设得更加美丽 (Making the Great Motherland More Beautiful).” August 29, 1. . 2017b. “续写塞罕坝的绿色传奇 (Continuing to Write the Green Legend of Saihanba)." August 4, 1.

Pernau, Margrit, and Helge Jordheim. 2015. "Introduction.” In Margrit Pernau, Helge Jordheim, Emmanuelle Saada, Christian Bailey, Einar Wigen, et al. (eds.). Civilizing Emotions: Concepts in Nineteenth-Century Asia and Europe, 1-24. Oxford: Oxford University Press.

Reed, Gay Garland. 1995. "Moral/Political Education in the People's Republic of China: Learning Through Role Models". Journal of Moral Education, 24(2), pp. 99-111.

Roetz, Heiner. 2013. "Chinese 'Unity of Man and Nature."' In Nature, Environment and Culture in East Asia: The Challenge of Climate Change, edited by Carmen Meinert, 23-39, Leiden: Brill.

Schmitt, Edwin A. 2016. "The Atmosphere of an Ecological Civilization: A Study of Ideology, Perception and Action in Chengdu, China." PhD dissertation, Hong Kong: Chinese University of Hong Kong.

Shen, Xiaoping 沈小平. 2015. “让科技创新成为生态文明的绿色引擎 (Making Sci-tech Innovations the Green Engine of Ecological Civilization)." Science \& Technology Daily 科技日报, May 12, 5 . 
Sternfeld, Eva. 2017. "Introduction". In Routledge Handbook of Environmental Policy in China, edited by Eva Sternfeld. London: Routledge, 1-15.

Shi, Ziqiang 史自强. 2017. “波取精神力量 践行绿色理念 (Drawing Spiritual Forces, Practicing Green Ideas).” People’s Daily 人民日报, August 26, 6.

Shin, Kyoung. 2017. "Neither Centre nor Local: Community-Driven Experimentalist Governance in China." The China Quarterly, vol. 231, September, 607-33.

Sørensen, Henrik H. 2013. "Of Eco-Buddhas and Dharma-Roots: Views from the East Asian Buddhist Tradition." In Nature, Environment and Culture in East Asia: The Challenge of Climate Change, edited by Carmen Meinert, 83-105. Leiden: Brill.

Tucker, Mary Evelyn, and John Berthrong (eds.). 1998. Confucianism and Ecology: The Interrelation of Heaven, Earth, and Humans. Cambridge, MA: Harvard University Press.

Tucker, Mary Evelyn, and Duncan Ryuken Williams (eds.). 1997. Buddhism and Ecology: The Interconnection of Dharma and Deeds. Cambridge, MA: Harvard University Press.

Wang, Guojun 王国军. 2014. “推进融入生态理念的科技创新 (Promoting Sci-tech Innovations Incorporating Ecological Ideals).” Guangming Daily 光明日报, March 22,6 .

Wang, Lihua 王利华. 2013. “从环境史研究看生态文明建设的“知”与“行 (“Theory” and 'Practice' in Ecological Civilization Viewed from Environmental History)." People's Daily 人民日报, October 27, 5.

Wu, Weizheng 武卫政, Liu, Yi 刘毅, and Shi, Ziqiang 史自强. 2017. “塞肎坝：生态文明建 设范例 (Saihanba: The Exemplar of Constructing Ecological Civilization)." People's Daily 人民日报, August 4, 1 .

Xinhua News Agency. 2015. “中共中央国务院矢于加快推进生态文明建设的意见 (CPC Central Committee and the State Council's General Guideline on Accelerating the Development of Ecological Civilization). ”People's Daily 人民日报, May 6, 1.

Zhu, Guangyao. 2016. Ecological Civilization: A National Strategy for Innovative, Concerted, Green, Open and Inclusive development." http://web.unep.org/ourplanet/march-2016/articles/ecological-civilization (accessed 26.09.2018). 